\title{
ВИЗНАЧЕННЯ ЕЛАСТИЧНОСТІ, ЗЧЕПЛЮВАНОСТІ, РОЗШАРУВАННЯ ПРИ ЗБЕРІГАННІ МОДИФІКОВАНИХ БІТУМІВ
}

\section{DETERMINATION OF ELASTICITY, COMPATIBILITY, DETERMINATION OF STORAGE OF MODIFIED BITUMES}

Талах Л.О., к.т.н., доц., Маліков В.В., к.т.н., доц., Панасюк Я.І., к.т.н., ст. викладач (Луцький НТУ, м. Луцьк)

Talakh L.O., Ph.D. associate professor, Malikov V.V, Ph.D. associate professor, Panasuk Y.I., Ph.D senior lecturer (Lutsk National Technical University, Lutsk)

Наведено результати експериментальних досліджень визначення еластичності, зчеплюваності (адгезії), розшарування при зберіганні дорожніх бітумів, модифікованих полімерноактивними добавками Kraton D1101, Calprene C-411, Calprene C-501 i восковою добавкою Sasobit.

Properties of asphalt and asphalt polymer composites as systems with a coagulation structure are determined mainly by the quality of bituminous binders. According to this, the quality indicators of the binding agents should be as objective as possible, allowing them to predict strength, displacement, cracks, water resistance and aging resistance of concrete on their basis.

Elasticity is the ability of bitumen-polymer binder to develop large deformations under the influence of external forces, and after the cessation of their action return to its original state. The essence of the method is to determine the part of the elastic (reversible) deformation in the general deformation of the sample.

Adhesion of bitumen is the strength of its adherence to the surface of the main or acidic stone materials in the contact area. When a pair of bitumen - the mineral surface is in a dry state, the adhesion of bitumen is always greater than its cogenesis (bitumen strength in a thin layer). When such a pair is in an aqueous medium, there is an extinction of the bituminous film from the surface of the stone material. This is due to the high polarity of water, which due to this well rubs the stone 
surface and penetrates it under the film of bitumen. In this regard, a useful indicator of the ability of bitumen to withstand the extinguishing action of the mineral surface is practically useful. Such an indicator is called clutter.

There are different methods of determining the adhesion. They are divided into passive and active ones. Passive clinging characterizes the ability of bitumen to resist flaking it from the mineral surface under the influence of water. Active clinging indicates the ability of bitumen to interact with the mineral surface in the presence of water and stick to it. Additionally, clamping properties can be determined qualitatively and quantitatively.

Stratification can lead to unpredictable consequences for the quality of asphalt polymer mixtures and asphalt polymer concrete. Determination of the degree of stratification makes it possible to use measures to eliminate it.

The essence of the method for determining the bundle is to determine the difference in the properties of the binder, modified by the polymer, from the upper and lower parts of the tube, which was maintained in an upright position at $180^{\circ} \mathrm{C}$ for 24 hours.

The results of experimental studies of determination of elasticity, adhesiveness (adhesion), stratification during storage of road bitumen, modified with polymeric active additives Kraton D1101, Calprene C411, Calprene C-501 and waxy additive Sasobit are given.

Ключові слова: бітум, модифікований бітум, добавка, еластичність, адгезія, розшарування при зберіганні.

Keywords: bitumen, modified bitumen, additive, elasticity, adhesion, stratification when stored.

Якість асфальтобетону багато в чому визначає в'яжуче, яке виготовляють на основі бітуму. Його властивості покращують різними методами, деякі 3 яких описано в працях [1-3]. Властивості асфальто- i асфальтополімербетонів як систем 3 коагуляційною структурою визначаються головним чином якістю бітумних в'яжучих. У відповідності 3 цим показники якості в'яжучих повинні бути в максимальній мірі об'єктивними, дозволяючи прогнозувати міцність, зсуво-, тріщино-, водостійкість і стійкість до старіння бетонів на їх основі. 
Ефективність дії модифікаторів визначають переважно 3 використанням методів визначення адгезійних властивостей бітумів. Дослідження еластичності, зчеплюваності (адгезіі), розшарування при зберіганні дорожніх бітумів, модифікованих полімерно-активними добавками Kraton D1101, Calprene C-411, Calprene C-501 i восковою добавкою Sasobit проводилося за методиками $[4,5,6]$.

За вихідну сировину був взятий бітум Кременчуцького НПЗ марки БНД 90/130 і бітум Мозирського НПЗ (Білорусь) марки 60/90. Процентний вміст в'яжучого складав 2\% і $3 \%$.

Еластичність - це здатність бітумополімерного в'яжучого розвивати великі деформації під дією зовнішніх сил, а після припинення їх дії повертатися в попередній стан. Сутність методу полягає у визначенні частини еластичної (оборотної) деформації у загальній деформації зразка.

Для виконання випробування розігріте до робочої температури $25{ }^{\circ} \mathrm{C}$ в'яжуче заливали у три форми «вісімки», витримували на повітрі протягом 60 хв, після чого надлишок зрізували гарячим ножем. Потім форми з в'яжучим витримували при температурі (25 \pm $0,5)^{\circ} \mathrm{C}$ протягом 60 хв, після чого знімали 3 пластин, відокремлювали боковини, розміщували на опірній площадці дуктилометра. Далі випробування виконували за правилами визначення розтяжності бітумів. Після досягнення розтягнення, рівного $(20,0 \pm 0,1)$ см по лінійці дуктилометра, двигун вимикали i зразки розрізали посередині ножицями. Зразки залишали у ванні дуктилометра $(60 \pm 2)$ хв при температурі $(25 \pm 0,5)^{\circ} \mathrm{C}$. За цей час скорочення зразка має бути не більшим 0,1 см за 15 хв. Після цього замірювали довжину обох частин зразка від зрізу кожної «напіввісімки» до торця форми.

Показник еластичності (Е, \%) розраховували за формулою:

$$
E=\frac{(20,0-3,0)-L}{20,0} \cdot 100 \%
$$

де 20,0 - довжина розтягнення зразка, см; 3,0 - відстань між торцями форми см; $L$ - сума довжин зразка від зрізу «напіввісімки» до їх кінця, см.

Розбіжність між результатами кожного випробування та середньоарифметичним не повинна перевищувати $10 \%$ від середньоарифметичного значення отриманих результатів. 

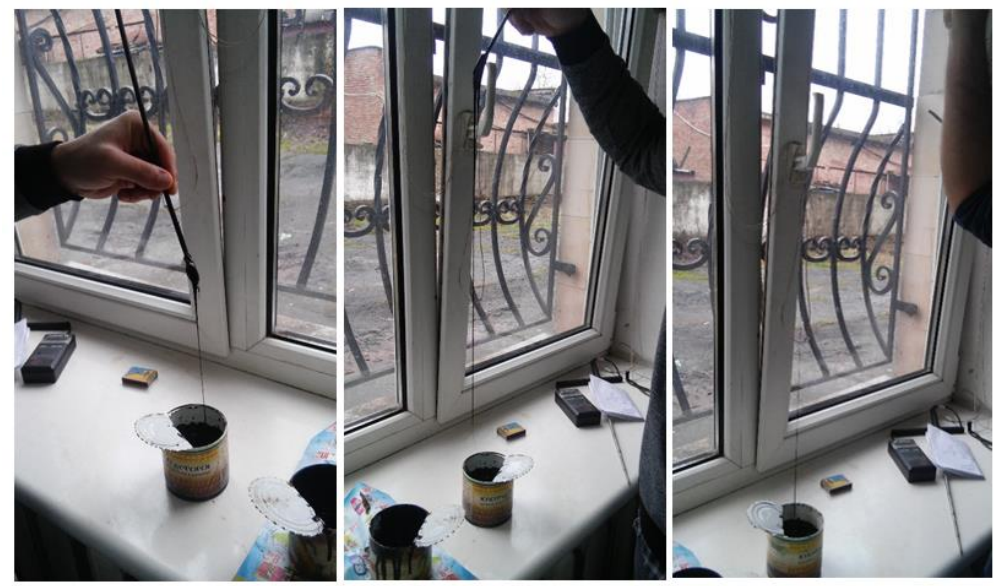

Рис. 1. Візуальне визначення еластичності

Всі інші випробування бітумів, модифікованих полімерами, виконуються за методиками, що використовуються для оцінки якості в’язких бітумів. При цьому пенетрація визначається при двох температурах $0^{\circ} \mathrm{C}$ та $25^{\circ} \mathrm{C}$, зчеплення зі склом визначається після термостатуванні у воді при температурі $85^{\circ} \mathrm{C}$.

Адгезія бітуму - це міцність його прилипання до поверхні основних або кислих кам'яних матеріалів в зоні контакту. Коли пара бітум - мінеральна поверхня знаходиться у сухому стані, то адгезія бітуму завжди більше ніж його когезія (міцність бітуму у тонкому шарі). Коли ж така пара знаходиться у водному середовищі, то відбувається відшаровування бітумної плівки від поверхні кам'яного матеріалу. Це обумовлено високою полярністю води, яка завдяки цьому добре змочує кам'яну поверхню та проникає по ній під плівку бітуму. В зв'язку з цим практично корисним $€$ показник, що характеризує здатність бітуму протистояти витискуючій дії мінеральної поверхні. Такий показник називається зчеплюваністю.

Існують різні методи визначення зчеплюваності. Вони розподіляються на пасивні та активні. Пасивна зчеплюваність характеризує здатність бітуму протистояти відшаровуванню його від мінеральної поверхні під дією води. Активна зчеплюваність 
свідчить про здатність бітуму взаємодіяти 3 мінеральною поверхнею у присутності води та приклеюватись до неї. Крім того, показники зчеплюваності можуть визначатись якісно та кількісно. У першому випадку показник зчеплюваності визначають, базуючись на візуальній оцінці площі бітумної плівки, що залишилась на

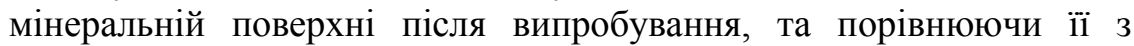
еталонним зразком. У другому випадку здійснюють кількісну оцінку цієї поверхні.

Визначення зчеплюваності модифікованого бітуму 3 мінеральною поверхнею може здійснюватись двома способами: кількісним по зчепленню зі склом згідно 3 методикою розділа «B'язкі дорожні бітуми» та якісним по зчепленню в'яжучого 3 поверхнею щебеню. За першим способом зразки витримуються у водяній бані при температурі $85^{\circ} \mathrm{C}$.

За другим способом за показник зчеплення приймається візуально у балах поверхня щебеню, що залишилась покритою плівкою в'яжучого після кип'ятіння в дистильованій воді. Випробування виконують на трьох зернах гранітного щебеню фракції (10-20 мм). Кожне зерно, попередньо помите, висушене та прогріте при температурі $(160 \pm 2)^{\circ} \mathrm{C}$ протягом години, обв'язують ниткою або тонким дротом і по черзі занурюють на 15 с в посудину 3 нагрітим до температури $(160 \pm 2)^{\circ} \mathrm{C}$ модифікованим бітумом, після чого виймають і підвішують на штативі на одну годину.

Після цього кожне зерно по черзі опускають у киплячу дистильовану воду, так щоб воно не торкалось стінок та дна склянки, та витримують у воді протягом 30 хв. В'яжуче, що спливає в процесі кип'ятіння, видаляють фільтрувальним папером. Після закінчення терміну кип'ятіння зерно щебеню переносять у склянку 3 холодною водою та візуально оцінюють якість зчеплення. Для цього використовують шкалу балів: плівка залишається по всій поверхні щебеню - 5 балів; плівка зміщується 3 гострих кутів та ребер - 4 бали; біля половини поверхні зерна залишається покритою плівкою в'яжучого - 3 бали; плівка зміщується водою 3 більшої частини поверхні зерна щебеню - 2 бали. 

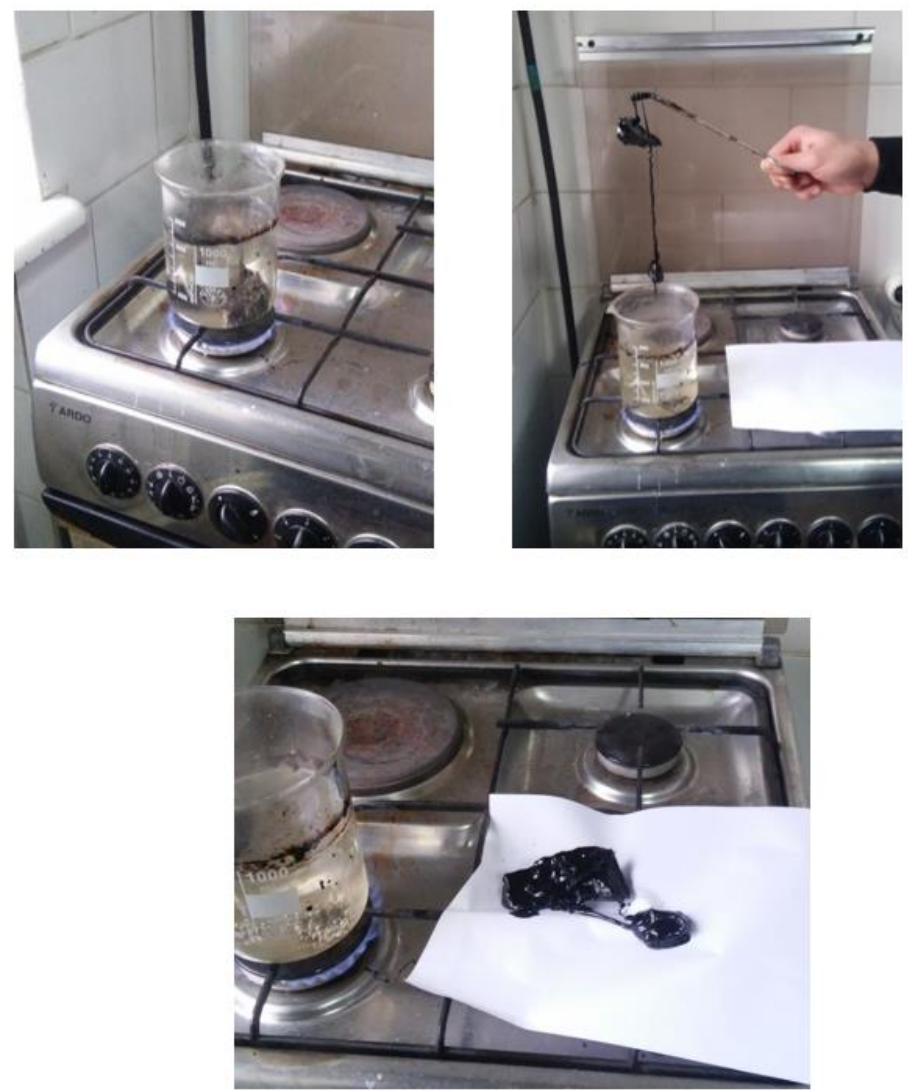

Рис. 2. Визначення зчеплюваності (адгезіi)

У процесі технологічної переробки бітумополімерне в'яжуче може зберігатися протягом довгого часу у робочих ємностях при високих температурах. У зв'язку 3 різною щільністю та недостатньою сумісністю бітуму і полімеру можливе розшарування в'яжучого на шар, насичений полімером та маслом (низькомолекулярними вуглеводнями), та шар, насичений асфальтенами і смолами. Таке розшарування може призвести до непередбачуваних наслідків щодо якості асфальтополімерних сумішей та асфальтополімербетону. Визначення ступеню 
розшарування дає можливість використати заходи по його усуненню.

Сутність методу 3 визначення розшарування полягає $у$ встановленні різниці властивостей в'яжучого, модифікованого полімером, 3 верхньої та нижньої частини тюбика, що його було витримано у вертикальному положенні при температурі $180{ }^{\circ} \mathrm{C}$ протягом 24 годин.

Для виконання випробування 150 г однорідного та чистого бітуму, модифікованого полімером, розміщували в окрему ємність, розігрівали до температури виготовлення в’яжучого та гомогенізували за допомогою мішалки. Заливали в'яжуче у виготовлені 3 алюмінію тюбики висотою 160 мм, діаметром 30-40 мм, запобігаючи утворенню повітряних бульбашок. Герметично закривали тюбики, щоб виключити контакт повітря 3 в'яжучим впродовж часу його термостатування.

Для запобігання видавлювання в’яжучого за рахунок його температурного розширення при нагріві стінки тюбика трохи сплющують. Після заповнення тюбика стискали стінки верхньої відкритої його частини на рівні трохи нижчому поверхні в'яжучого. При цьому в щілині між стінками тюбика має 3'явитись плівка в’яжучого, після чого край тюбика загинали кілька разів. Герметично закритий тюбик розміщували на штатив-підставку у вертикальному положенні i весь пристрій ставили у нагріту до температури $(180 \pm 5)^{\circ} \mathrm{C}$ сушильну шафу.

Після термостатування протягом 24 годин виймали штативпідставку, охолоджували тюбик до кімнатної температури, а потім ставили в холодильну камеру i витримували при температурі близько мінус $20^{\circ} \mathrm{C}$ протягом 30 хв. Діставали тюбик 3 камери i, не гаючи часу, відшаровували алюмінієву стінку від в'яжучого. Гарячим ножем розрізали циліндричний зразок на три рівні, частини. Верхню та нижню частини розміщували у відповідні ємності.

Всі інші випробування бітумів, модифікованих полімерами, виконували за методиками, що використовуються для оцінки якості в'язких бітумів. При цьому пенетрація визначається при двох температурах $0^{\circ} \mathrm{C}$ та $25^{\circ} \mathrm{C}$, зчеплення зі склом визначається після термостатуванні у воді при температурі $85^{\circ} \mathrm{C}$. 


\section{Висновки} (до $80 \%$ ).

1. Модифіковані Kraton D1101 бітуми мають високу еластичність

2. Добавка Kraton D1101 у бітуми після 48 год. зберігання розшаровується, майже не покращує адгезію.

3. Термоеластопластами Calprene C-411 (радіальний) працює більш активно, ніж Calprene C-501 (лінійний) і забезпечує вищу еластичність при однаковому вмісті полімерів (60-85 \%).

4. Спостерігається значне розшарування модифікованих бітумів при зберіганні. Особливо це стосується бітумів, модифікованих 3 \% Calprene C-411 та Calprene C-501.

5. Введення $2 \%$ Sasobit адгезія дещо покращується (до $60 \%$ або 3 бали); вміст 3 \% добавки підвищує зчеплення бітуму 3 мінеральним матеріалом до 80-90 \% або 4 балів.

6. Бітум 3 Sasobit не розшаровується i виявляє високу термостабільність при зберіганні.

7. Добавка Sasobit $€$ структуруючою високомолекулярною речовиною, на відміну від полімерних модифікаторів типу термоеластопластів, не надає модифікованим бітумам еластичності.

\section{Список використаної літератури}

1. Жданюк, В. К. Дослідження впливу добавок "Sasobit" та "Toptex В", як модифікаторів бітуму, на властивості щебенево-мастикового асфальтобетону [Текст] / В. К. Жданюк, Д. Ю. Костін, І. В. Ничипорук, Р. С. Гураль // Автошляховик України. - 2013.- № 3.- ${ }_{\Gamma}$ С. 22-26. 2. Модифицированные битумные вяжущие, специальные битумы и битумы с добавками в дорожном строительстве / Пер. с французского под ред. В. А. Золотарева и В.И. Братчуна. - Харьков : Изд-во ХНАДУ, 2003. - 229 с. 3. Золотарьов, В. О. Полімербітумне в'яжуче для асфальтобетону [Текст] / В. О. Золотарьов, Л. В. Столярова, Ю. Ф. Гончаренхо // Автошляховик України. - 2000.- № 2.- ${ }_{\Gamma}$ С. 30-32. 4. Будівельні матеріали. Бітуми дорожні, модифіковані полімерами. Технічні умови ДСТУ Б В.2.7-135:2007. - К.: Держбуд України, 2007 - 32 с. 5. Матеріали на основі органічних в'яжучих для дорожнього i аеродромного будівництва. Методи випробувань - ДСТУ Б В.2.7-89. Зміна № $1-$ К.: Держбуд України, 2002 - 54 с. 6. Приготування та застосування дорожніх бітумів, модифікованих адгезійними добавками на основі катіонних поверхнево-активних речовин - ДСТУ-Н Б В.2.7-254:2012. - К.: Мінрегіон України, 2012 - 16 с. 